Looking in the mirror: Reflecting on 25 years of Inclusive Education in Australia

Joanna Anderson*

Christopher Boyle

Graduate School of education, University of Exeter, Exeter, United Kingdom

*Joanna Anderson-ja490@exeter.ac.uk 


\section{Looking in the mirror: Reflecting on 25 years of Inclusive Education in}

Australia

\section{Abstract}

Australia was an early signatory to the Salamanca Statement, and it espouses inclusive education (IE) as the overarching philosophy of education for all. A 2015 critique of IE in Australia (Anderson and Boyle 2015) found that while some gains had been made, particularly in the recognition of the needs of some of the nation's minority groups, the lack of a nationally accepted understanding of IE meant that it was transpiring in fundamentally distinctive ways across the eight education jurisdictions, with different outcomes for different groups of students. This paper reflects upon why Australia has struggled to enact the recommendations outlined in the Salamanca Statement a quarter of a century ago. The impacts of current education reforms, including the current model of educational provision, the understanding of disability and educational need, and the neo-liberal concepts of standardisation, measurement, and choice are explored. It challenges the idea that IE is the work of schools, and instead argues the need for a national approach to IE. Governments must acknowledge the barriers that their current policies and structures erect and shift towards a more inclusive model of educational delivery - for the benefit of all children and young people in Australia.

Key words: Inclusive education, the Salamanca Statement, Australia, Neoliberalism, education reform

\section{Introduction}

A quarter of a century ago a conference of more than 300 participants constituted what has been described as 'the most significant document that has ever appeared in the field of special education' (Ainscow and César 2006, 231). Named after the town in which it was created, the Salamanca Statement (UNESCO 1994) depicted 'a worldwide consensus on future directions for special education needs' (iv), a future underpinned by Inclusive education (IE), where schools for all 'include everybody, celebrate differences, support learning and respond to individual needs' (iii). The Statement provided a Framework for Action, designed to guide 
governments towards the establishment of inclusive school systems. For the first time IE was on the global agenda. Governments were asked to place IE at the forefront of education policy and reform, and they did. Yet 25 years on many countries are still struggling to provide schools for all, from the seemingly simple task of defining what it is they are working towards, to the more complex challenges of delivering IE (Schwab, Sharma, and Loreman 2018).

Exclusion has revealed itself as 'a stubborn foe' (Slee 2018, 17). It seems the impassioned and tireless work of many since 1994 has had minimal, if any, impact on reducing engrained exclusionary practices in education (Boyle and Anderson Working Draft). There is no doubt that the Salamanca Statement has elicited positive changes in some areas. Students who were once not considered educatable are now accessing school (Boroson 2017), and discourse on equity has become part of the ongoing educational debate. Yet IE is a long way from becoming the norm. Why? What has proven so challenging, that despite governments agreeing to pursue IE, systems globally are still to reach this ideal? These questions will be explored through one nation's experiences of IE over the past 25 years, Australia.

\section{IE in Australia}

Australia was an early signatory to the Salamanca Statement, and since 1994 has espoused IE as the overarching philosophy for the education of all students. Yet, similar to many other nations, Australia has struggled to achieve what was laid out in the Framework for Action, despite having IE at the forefront of its educational rhetoric and policy for 25 years. Interrogating the reasons behind this brings to the surface a myriad of contradictions and paradoxes in Australia's educational reform agenda, and its place within broader sociopolitical and socio-cultural contexts. Before exploring these notions, it is necessary to understand the complex nature of providing education in Australia.

\section{A brief history}

Changes to the way Australia considered the education of children with disabilities began in the 1970 's. Before this time, students deemed to be 'educable' or 'trainable' were placed into special schools, but many students with more complex or profound disabilities did not attend school at all (Loreman, Deppeler, and Harvey 2011). In 1973 the Schools in Australia report, 
more affectionately referred to as the Karmel report, insisted in a valuing of diversity and advocated for the notion of integration. It recommended that governments fund schools appropriately to allow students with disability access to their local schools. History shows that while this notion was accepted by educational policy makers, and in fact by the end of 1981 every educational jurisdiction in Australia had a policy for students with a disability, what ensued 'did not significantly reduce inequalities in educational outcomes among different groups. Indeed, it could be said that a culture developed in which it was acceptable to label students and to entertain low expectations for certain groups of young people' (ACER 1998, 4). While Karmel's recommendations did not produce the intended outcomes, it did pave the way for the notion of IE. The Salamanca Statement was the impetus for change, and it was the Framework for Action that propelled IE to the forefront of the Australian educational agenda.

The ensuing decade saw some big changes. Large numbers of students left special education settings and enrolled in their local schools, with many of these segregated facilities closing their doors (Forlin 2006). As this was taking place, many states and territories conducted their own reviews into the education of students with a disability, generating recommendations to improve outcomes for these students while adopting IE as the preferred model of education delivery. The federal government undertook its own project and introduced the Disability Standards for Education 2005 (DSE), a document outlining in explicit detail the requirements of education systems under the Disability Discrimination Act of 1992. Despite this seemingly rapid progress towards IE by those developing the policies, Forlin's (2006) reflection on the state of things ten years after the Salamanca Statement revealed that many of the educational structures, such as curriculum, pedagogy, teacher training and resourcing, were in fact 'disabling', and while efforts were being made to address them, it was being done with limited success.

In 2008 education ministers from around the nation, as well as the federal education minister, convened to sign off on a policy document that would set the agenda for the future of education in Australia - The Melbourne Declaration on Educational Goals for Young Australians (Ministerial Council on Education, Employment, Training and Youth Affairs). Two goals were described; Goal 1 - Australian schooling promotes equity and excellence; Goal 2 - All young Australians become successful learners, confident and creative individuals, and active and informed citizens (6). The rhetoric used in this document was 
important as no distinction was made between students with and without disability. The goals were set for all students, and from this time IE in Australia became about the successful education of all students (Berlach and Chambers 2011). Students with disabilities (including those with mental health disorders), students with learning difficulties, students from low socio-economic backgrounds, indigenous students, students form migrant families (particularly those from Asia, Africa and the Middle East), students who identified as LGBTIQ+, and students form other minority or disadvantaged groups, were all placed under the IE umbrella. A decade on from the release of this nationally 'shared vision for education', Verity Firth, the education minister from New South Wales (2008-2011) who was involved in its development, described progress towards meeting the goals as being 'desperately disappointing' (Sydney Morning Herald, December 3, 2018). A pledge to review the Declaration in 2019 has been made by the current federal education minister. Some of the blame for the challenges faced by the Melbourne Declaration may well lay in the structures of the education system itself.

\section{The puzzle of responsibility}

The provision and funding of education in Australia is complex (Dinham 2008), perhaps more so that it should be given it is a nation of just 25 million people. Australia has three well defined, and very separate, education sectors - the government run sector (state or public schools), and the non-government sector which comprises of both independent and catholic schools. These schools operate within each of the eight states and territories and funding this schooling system is an intricate process. The majority of funding for the government sector comes from the states and territories, with the Australian Government a minority public funder of this sector. The Australian Government is the majority public funder for nongovernment schools, with state and territory governments providing minority public funding (Department of Education and Training 2018). This model has been described as 'unnecessarily complex' (Gonski et al. 2011, xiv), but despite reviews completed in 2011 (Gonski et al. 2011) and again in 2018 (Gonski et al. 2018) recommending changes that would see the introduction of a national, needs based funding model, things have not significantly changed. Some attempt to understand the needs of students has been made with a national database of students with disability and their associated levels of required adjustments (Nationally Consistent Collection of Data on school students with disability (NCCD)) established, and in 2017 every school in Australia provided data. While the notion 
of understanding disability and its impact on educational success is certainly worth acknowledging, the focus for this database is narrow, and as yet has not made a significant difference to the funding or resourcing received by schools to support the education of all students. It has certainly not prompted any systemic reform, despite classrooms in Australia becoming increasingly diverse.

\section{Diversity in the classroom}

Australian schools comprise a complex mix of students from varied and diverse backgrounds (Carter and Abawi 2018), and the rate of this diversity is on the rise. The 2016 census revealed some interesting data. The number of students with a disability who require support to access school is increasing, with the biggest increase seen in boys where $4.4 \%$ of boys 5 14 now have a disability (Fischer and Robinson 2017). More students from Aboriginal and/or Torres Strait Islander backgrounds are attending school (ABS 2018), and there are an increasing number of students identifying as LGBTIQ+ (ABS 2018). Classrooms are becoming increasingly multicultural, with more diverse ethnic, religious and language groups represented. Around 15\% of the nation's student population are bilingual and from diverse socio-cultural backgrounds (Shahaeian 2014), and there are an increasing number (although this is still relatively small) of students who are refugees (Miller, Ziaian, and Esterman 2017). Income inequality is increasing and, as a result, there has been an increase in the number of children and young people living in poverty, with one child in every six now living below the poverty line (ACOSS 2016). When viewed in this way, the need for IE to be the underpinning philosophy of education delivery in all Australia schools becomes increasingly evident.

\section{Neo-liberalism, social justice and IE}

The Salamanca Statement, in a single paragraph, describes IE as a means of "combating discriminatory attitudes, creating welcoming communities' (ix) and 'building an inclusive society' (ix), with the notion of it being about 'education for all' coming after these points (ix). This is not a criticism but rather a demonstration of the responsibility education is given, globally, to help 'fix' social injustices, such as the exclusionary practices that impact particular groups of people. However, some argue that this onus of responsibility placed onto schools and the systems in which they operate, is unfair. Apple (2015) contests that by placing the burden of change at the feet of education, other facets of current societal 
structures and practices that should be challenged (such as social class and economic power), are not. Education becomes the scape goat. While this point is well made, evidence dictates that educational attainment is one construct that does lead to improved life outcomes, and as such, education that serves all is worth fighting for, particularly in a nation with a diverse student population, such as Australia.

Underpinning much of what is presented in the Salamanca Statement is the notion that IE, successful IE, requires systemic change at a national level. Outlined clearly is the responsibility of government to ensure legislation, policy, funding, structures, and resourcing all support IE practices. Given the role of government in education, it is impossible to separate educational reform from the political zeitgeist in which it is occurring (Anderson, Boyle and Deppeler 2014). Education is 'an inherently political act' (Aasen, Proitz, and Sandberg 2014, 721) and understanding the role politics and government play is crucial when interrogating any piece of education reform, particularly one as ambitious and wide-reaching as the Salamanca Statement.

The 'language, ideas and policies' of neo-liberalism (Denniss 2018, 2), the prevailing political economic paradigm globally (Glendenning 2015), have in the past thirty years permeated not only the economies of countries, but also their cultures (Denniss 2018). The underpinning belief of neo-liberalism is that any market solution will be better than that which could be offered by any other, as 'the profit motive of companies, combined with consumers' ability to choose the product that suits them best, will result in the best possible social and economic outcomes' (Denniss 2018, 33). The influence of neo-liberalism on education globally has been significant (Aasen, Proitz, and Sandberg 2014, 721). Education has come to be about those principles that are commonly attributed to neo-liberalism marketisation, competition and profit (Apple 2017) - principles that are 'less centred on the social motive of education and more oriented towards market efficiency' (Arduin 2015, 108). This has seen concepts such as choice, growth, standardisation, and improvement enter the educational discourse and policy of many countries (Niesche and Keddie 2016), including Australia. It becomes evident, when viewed from this perspective, why IE has struggled to find its place within Australia's current reform agenda; reform, which has included the national curriculum, the National Assessment Program Literacy and Numeracy (NAPLAN) and the My School website, has been driven by a neo-liberal paradigm, despite this being in fundamental contradiction to IE (Hall et al. 2004). 


\section{A national curriculum: Standardisation}

Recent years have seen Australia adopt a national curriculum for this first time in its relatively short schooling history. Developing a standard curriculum was not an easy task and there were a number of aborted attempts before the states and territories finally agreed upon what is known today as the Australian Curriculum. Debate has ensued since the release of these documents, with many contentious issues being raised: the curriculum does not fairly represent 'Western Civilisation' (Cairns 2018); the curriculum does not contain enough religious content (Statham 2014); the curriculum does include enough indigenous history (Foley and Muldoon 2014); the curriculum does not contain enough queer content (Jagose, Wallace, and Rawlings 2019); the curriculum does not meet the needs of students with a disability (Bonati, Little, Evans, and Spandagou 2014). It is not surprising that these concerns are being voiced. Any attempt to standardise a curriculum involves decisions being made about what is included and what is not, and these decisions are made by those with the power to do so (Mulcahy 2008). Harris (1979) described this process as political manipulation and it can have the consequence of perpetuating rather than challenging educational inequalities. For students in Australia, this means that whether they are attending school in a high rise building in Melbourne, or gaining their education via school of the air from a remote property in the middle of the desert, whether they have a diagnosed intellectual impairment, are identified as gifted and talented, or have just arrived in the country from a non-English speaking background, they are all working on the same curriculum content, at the same time, with the same set of expected outcomes. A standard curriculum works for some, but not for all. There are 'winners and losers' (Artiles 2003, 166), determined by performance against the set standards; if students surpass these outcomes they are considered to be doing well, but if not, they are failing. It can be deduced that students whose experiences align with the curriculum will be the 'winners', and those students who do not fit within the context of the curriculum, will be the 'losers'.

\section{NAPLAN: Measurement}

The year 2008 saw the first sitting of the National Assessment Program Literacy and Numeracy (NAPLAN) tests. Since then, students in Australia in Years 3, 5, 7 and 9 have sat the Reading, Writing, Language Conventions (spelling, grammar and punctuation) and Numeracy tests annually, and this continues. While purported to be a low stakes method of data collection, Mayes and Howell (2018) contest that the way in which the NAPLAN data 
has been used (performance comparisons, policy direction, league tables published in the media) is consistent with high-stakes testing. Criticism about NAPLAN has been consistent since its inception, and while exploring all of the issues is beyond the scope of this paper, one issue does need to be unpacked in a discussion about IE - access to and participation in the tests. The implementation of NAPLAN requires the following of strict confidentiality and compliance procedures, and as part of this, applications to use adjustments to support access to the tests must be made prior to the tests, some as early as three months before the sitting of the tests. Adjustments are restricted (Davies, Elliot, and Cumming 2016) and include supports such as the use of a scribe or AUSLAN interpreter (if normally accessed by the student), breaks (very short, supervised breaks), and additional time (again, only a short amount of additional time is recommended) (NAP 2016a). While little changed in the first eight or so years (Anderson and Boyle 2015), since the development of NAPLAN online further supports have been provided to assist with access, including the capacity to use some forms of assistive technology (NAP 2016a), though many of the accessibility features that students would use on their digital devices are not available. However, some things remain as they have been. Students with an intellectual disability can be automatically exempt, so while they are considered to have not met the national minimum standard (NMS), information about what they can and cannot do is not collected. The past ten years of NAPLAN has seen a marked increase in the number of students not participating in tests, through either being exempt, withdrawn, or not coming to school. In 2008, 4.7\% of students in Year 3 did not sit the reading test. In 2017 that number was 7\%. In numeracy the percentage increased from $5.7 \%$ to $7.3 \%$. For students in Year 9 the figures are even worse. In 2008 8.2\% of students did not sit the reading test and $8.1 \%$ the numeracy test. In 2017 the numbers were $10.7 \%$ and $11.3 \%$ respectively. This means that there are statistically significant numbers of students who are not having their data collected and counted in the collation of information that is used by all levels of government in Australia to determine and enact education policy. Where do these students fit within the level of educational ability and advantage? At the bottom end of course. It is estimated that more than one third of students across Australia with additional needs, whatever that may be, do not participate in the NAPLAN testing regime (Dempsey and Davies 2013). So, one third of an already disadvantaged group are not able to contribute to the data being collected to make decisions about their educational needs. This is an interesting paradox as NAPLAN is described as being a driver for equity in education (NAP 2016b). 


\section{My School: Choice}

As the national curriculum and NAPLAN were being developed and implemented, so too was the My School website. The development of this site, as described by the then Prime Minister Kevin Rudd, was in response to the standards in schools not being high enough and the provision of this information would allow parents to 'vote with their feet' when determining a school for their children (Riddle 2017). The My School site provides information on every school in Australia, not only about academic results, but also about the types of students that are enrolled at the school (such as socio-educational advantage and indigeneity); parents can choose a school by results, or by peer group (Rowe and Lubiensk 2017). This notion of choice presupposes two conditions; firstly, all parents are in a position to make a credible decision about the quality (or not) of their children's schooling (Hutchings 2017) and secondly, they all have the financial and social means to send their children to the school of choice. This is not the case. As a consequence, students who are 'lower achieving' or do not fit behavioural or social norms, often end up attending poorer performing schools (Ainscow 2010). This cycle of low achievement is then perpetuated as poor results lead to 'poor performing' schools which in turn lead to poorer results and so on (Hutchings 2017). Achievement in Australia is becoming increasingly linked to the 'level of advantage of the school a student attends' (Bonner 2019, 2). The result? 'The disadvantaged are being segregated into struggling schools so that the burden of lifting up the most disadvantaged is not evenly spread across schools, sectors and locations.' (Bonner 2019, 2).

\section{Inclusive education}

Despite the national development and implementation of the reforms described above, IE has been left to the states and territories to manage, and their response in many cases, has been to place the responsibility for it at the feet of schools. Two years ago, the State Government in Queensland, one of the biggest states in Australia (both in land mass and population), commissioned a review into the education of students with disability. Deloitte Access Economics (an interesting choice in itself) conducted the review, and found that in Queensland, as many other 'reviews and inquiries across Australia have demonstrated, there remains a disparity between today's policy and practice and that required to inclusively support every student achieving to the maximum of their potential' (Deloitte Access Economics 2017, iii). The government's response was to develop two new policies, with the onus of responsibility for the implementation of these given to schools with very little 
guidance or additional support. Only time will tell whether this renewed push for IE proves successful.

This state by state approach to IE has led to another issue. There is no national consensus on what constitutes a disability in education, or consistency in the way students are resourced. A stark example is seen in two states that border each other, New South Wales (NSW) and Queensland. Consider the 'Twin Towns' of Tweed Heads and Coolangatta on the NSW/Queensland border. A student attending school in Tweed Heads, NSW, with a diagnosed mental health disorder or behavior disorder would be acknowledged as having a disability and resourced as such. However, if they moved the two kilometers north and enrolled at school in Coolangatta, Queensland, their disorders would not fit one of this state's six disability categories and therefore would not be eligible for support. Gonski (2011) highlights that this extends to disadvantage as well, and notes that the disparity in funding for these students is exacerbated by 'the different methods used to define some groups of disadvantaged students across states and territories' (134). While some attempt has been made to collect data at a national level on student need through the NCCD (as described earlier on in the paper), there is no consistent approach to either understanding the diverse range of needs that students have when they come to school, or identifying the best ways in which to support these needs. A 2016 Senate report into the education of students with a disability found that 'the experience of students with disability in the school system in Australia varies widely, depending on multiple factors, including the family's financial means, geographical location and indigeneity' (Education and Employment Refences committee 2016,9). There is no evidence to refute the notion that this is not the case for many students from disadvantaged backgrounds in Australia.

Armstrong (2017) describes the effect of neo-liberalism on inclusive and special education as a 'wicked problem' in recognition of the complexity of the issue. IE does not sit comfortably within the neo-liberal paradigm (Anderson and Boyle Accepted), and having it placed alongside the reforms described above highlights the fact that current educational discourse and policy are imbued with paradoxical values and colliding agendas (Furlong 2013). IE, as part of Australia's educational rhetoric and policy, 'has become an empty language' (Slee 2018, 20).

\section{Looking in the mirror}


The Salamanca Statement stipulates that 'regular schools with (an) inclusive orientation are the most effective means of...achieving education for all' (ix). Measuring the outcomes of any attempts to enact this is difficult, as IE does not present with a set of standards with which to assess achievement (Forlin et al. 2013). Loreman (2014) suggests using a range of tools in unison to measure the success of IE, through investigating student participation, student achievement, and postschool outcomes. Using this approach, Australia's response to the Salamanca Statement can be interrogated and conclusions drawn about it whether or not it has managed, under its reform agenda over the past 25 years, to successfully enact the principles it agreed to uphold.

Table 1. Australia's IE report card - INSERT TABLE HERE

\section{In a nutshell}

Australia is failing in its commitment to the Salamanca Statement. A report released in 2015 looking into educational opportunity in Australia (Lamb et al. 2015) found that students for whom the current schooling system is not working 'are disproportionately likely to be from disadvantaged backgrounds. Success at each stage (of education) varies by Indigenous status, language background, region and gender, and markedly by the socio-economic status (SES) of students' (iv). The evidence presented above does not show any marked improvement in outcomes for these students since 2015, and in many cases, it attests that things are getting progressively worse.

Australia now sits equal fourth (out of the 36 countries in the OECD) for having one of the most segregated school systems, with the educational attainment gap between students from advantaged backgrounds and those from disadvantaged backgrounds now one of the highest in the OECD (OECD 2018). This does not reflect the decision that was made by the Australian Government a quarter of a century ago, to become one of the first signatories to the Salamanca Statement. Perhaps it is as Slee (2018) laments, 'exclusion is an ontological given, part of our social, and therein our educational, DNA or zeitgeist' (17). Whether this is the case or not, the status quo should be challenged, and ideas, big ideas, should be put forward to disrupt current ways of thinking and doing things. As Bregman (2017) notes:

'If we want to change the world we need to be unrealistic, unreasonable, and impossible. Remember: those who called for 
the abolition of slavery, for suffrage for women, and for samesex marriage were also once branded as lunatics. Until history proved them right' (264).

\section{Where to next?}

The educational disadvantage that is exists in Australia is endemic of a system that rewards some and discards others. School reform can help, but to see any real progress things need to change at a system and structural level (Perry 2017). This is unless, as Bonner (2019) argues, 'we prefer to believe that Australia's more distant, less advantaged and fully inclusive schools are collectively falling behind due to their own inadequacies' (14). Time for this kind of thinking is over. The Salamanca Statement identified systemic change at a national level as being necessary, yet consecutive Australian governments, from all sides of politics, have failed to acknowledge this. But this is what is needed if an education system that is inclusive of all of those for whom it is responsible, is possible. Scholars, researchers and educationalists need to stand up and agitate for change, real change, that challenges the status quo (Reindal 2016) and the 'underpinning beliefs and behavioural motivations - as well as political forces - which currently sustain them' (Armstrong 2017, 5). Any work to create more inclusive schooling will require 'the transformation of the philosophy, values and practices of entire educational systems' (Artiles, Harris-Murri and Rostenberg 2006, 260). Other nations, such as Finland and New Zealand (Perry 2017), have started this journey, and while neither country can claim a perfect system that meets the needs of all students, both have more equitable and inclusive systems than Australia. Progress is possible. As a nation Australia needs to recommit to the principles of the Salamanca Statement and work towards creating an education system that delivers positive outcomes, for each and every one of its diverse student population. A natural starting point would be the establishment of a nationally accepted understanding of inclusive education, and the development of an Australian Framework for Action to make successful and inclusive schooling a reality for all children, no matter who they are, the circumstances in which they live, or their postcode. 


\section{References}

Aasen, P., T. Proitz, and N. Sandberg. 2014. "Knowledge Regimes and Contractions in Education Reforms.” Educational Policy 28 (5): 718-738. doi: $10.1177 / 0895904813475710$

Ainscow, M. 2010. “Achieving Excellence and Equity: Reflections on the Development of Practices in One Local District over 10 years." School Effectiveness and School Improvement: An International Journal of Research, Policy and Practice 21 (1): 75 92. doi: 10.1080/09243450903569759

Ainscow, M. and M. César. 2006. "Inclusive Education Ten Years After Salamanca: Setting the Agenda." European Journal of Psychology of Education 21 (3): 231-238. doi: 10.1007/BF03173412

Anderson, J. and C. Boyle. Accepted. "Including into What? Reigniting the 'Good Education' Debate in an Age of Diversity. In Inclusive Education: Global Issues and Controversies, edited by C. Boyle, J. Anderson, A. Page and S. Mavropoulou, (Chapter 2), Netherlands: Brill Publishers.

Anderson, J. and C. Boyle. 2015. "Inclusive Education in Australia: Rhetoric, Reality and the Road Ahead." Support for Learning 30 (1): 4-22. doi: 10.1111/1467-9604.12074

Anderson, J. C. Boyle, C., and J. Deppeler. 2014. "The Ecology of Inclusive Education: Reconceptualising Bronfenbrenner." In Equality in Education: Fairness and Inclusion, edited by Z. Zhang, P. W. K. Chan, and C. Boyle, 23-34. Rotterdam: Sense Publishers.

Apple, M. 2017. "What is Present and What is Absent in Critical Analyses of Neo-liberalism in Education." Peabody Journal of Education 92 (1): 148-153. doi: 10.1080/0161956X.2016.1265344

Apple, M. 2015. "Reframing the Question of Whether Education Can Change Society." Educational Theory 65 (3): 299-315. doi:10.1111/edth.12114

Arduin, S. 2015. "A Review of the Values That Underpin the Structure of an Education System and Its Approach to Disability and Inclusion." Oxford Review of Education 41 (1): 105-121. doi: 10.1080/03054985.2015.1006614

Armstrong, D. 2017. "Wicked Problems in Special and Inclusive Education." Journal of Research in Special Educational Needs 17 (4): 229-236. doi: 10.1111/14713802.12402 
Artiles, A. 2003. “Special Education's Changing Identity: Paradoxes and Dilemmas in Views of Culture and Space.” Harvard Educational Review 73 (2): 164-202. Retrieved from https://search-proquest-com.ezproxy.une.edu.au/docview/212297401/fulltextPDF

Artiles, A., N. Harris-Murri, and D. Rostenberg. 2006. "Inclusion as Social Justice: Critical Notes on Discourses, Assumptions, and the Road Ahead." Theory into Practice 45 (3): 260-268. doi: 10.1207/s15430421tip4503_8

Australian Bureau of Statistics (ABS). 2018. 4221.0 - Schools, Australia, 2017. Retrieved from http://www.abs.gov.au/ausstats/abs@.nsf/Lookup/4221.0main+features22017

Australian Council for Educational Research (ACER). 1998. "Schools in Australia: 19731998 The 25 Years Since the Karmel Report (Conference Proceedings)". Retrieved from http://research.acer.edu.au/research_conference_karmel/1

Australian Council of Social Service (ACOSS). 2016. Poverty in Australia 2016. Strawberry Hills, NSW: Australian Council of Social Service. Retrieved from https:/www.acoss.org.au/wp-content/uploads/2016/10/Poverty-in-Australia-2016.pdf

Australian Curriculum and Reporting Authority (ACARA). 2017. National Report on Schooling in Australia 2016. Retrieved from http://www.acara.edu.au/reporting/national-report-on-schooling-in-australia Australian Curriculum and Reporting Authority (ACARA). 2016. Student Attendance. Retrieved from http://www.acara.edu.au/reporting/national-report-on-schooling-inaustralia-data-portal/student-attendance

Australian Institute of Health and Welfare (AIHW). (2018). Children's headline indicators. Canberra: AIHW. Retrieved from https://www.aihw.gov.au/reports/childrenyouth/childrens-headline-indicators

Australian Institute of Health and Welfare (AIHW). 2017. Disability in Australia: Changes Over Time in Inclusion and Participation in Education. Canberra: AIHW. Retrieved from https://www.aihw.gov.au/getmedia/34f09557-0acf-4adf.../Education20905.pdf.aspx

Berlach, R. and D. Chambers. 2011. "Interpreting Inclusivity: An Endeavour of Great Proportions." International Journal of Inclusive Education 15 (5): 529-539. doi: $10.1080 / 13603110903159300$

Bonati, M., C. Little, D. Evans, and I. Spandagou. November 12 2014. Separate Curriculum for Students with Disability No Good for Anyone. Commentary in The Conversation. Melbourne, Australia: The Conversation Media Group. Retrieved from 
https://theconversation.com/separate-curriculum-for-students-with-disability-nogood-for-anyone-33891

Bonnor, C. 2019. Separating Scholars: How Australia Abandons Its Struggling Schools. Sydney, Australia: Centre for Policy Development.

Boroson, B. 2017. "Inclusive Education: How has Education Evolved from Exclusion to Inclusion, from Judgment to Acceptance, and from Disability to Difference?" Educational leadership 74 (7): 18-23. Retrieved from https://eric.ed.gov/?id=EJ1138108

Boyle, C. and J. Anderson. Working draft. "Inclusive Education at a Crossroads: Where to From Here?". Oxford Encyclopedia of Inclusive Education.

Bregman, R. 2017. Utopia for Realists and How We Get There. London: Bloomsbury. Cairns, R. June 6 2018. 'Western Civilisation'? History Teaching Has Moved On, and so Should Those Who Champion It. Commentary in The Conversation. Melbourne, Australia: The Conversation Media Group. Retrieved from https://theconversation.com/western-civilisation-history-teaching-has-moved-on-andso-should-those-who-champion-it-97697

Carter, S. and L. Abawi. 2018. "Leadership, Inclusion, and Quality Education for All." Australasian Journal of Special and Inclusive Education 42 (1): 49-64. Retrieved from https://www-cambridge-org.ezproxy.une.edu.au/core/journals/australasianjournal-of-special-and-inclusive-education/article/leadership-inclusion-and-qualityeducation-for-all

Children and Young People with Disability Australia (CYDA). 2017. CDYA Education Survey 2017. Retrieved from https://www.cyda.org.au/education-survey-results-2017 Closing the Gap (CTG). 2019. Closing the Gap Report. Canberra, Australia: Department of the Prime Minister and Cabinet, Australian Government. Retrieved from https://ctgreport.pmc.gov.au/

Cooc, N. and E. Kiru. 2018. "Disproportionately in Special Education: A Synthesis of International Research and Trends." The Journal of Special Education 52 (3): 163 173. doi: $10.1177 / 0022466918772300$

Cunneen, C. 2013. “Time to Arrest Rising Aboriginal Prison Rates.” Insight 1(8): 22-24. Retrieved from http://insight.vcoss.org.au/time-to-arrest-rising-aboriginal-prisonrates/

Davies, M., S. Elliott, and J. Cumming. 2016. "Documenting Support Needs and Adjustment Gaps for Students with Disabilities: Teacher Practices in Australian Classrooms and 
on National Tests.” International Journal of Inclusive Education 20 (12): 1252-1269. doi: $10.1080 / 13603116.2016 .1159256$

Dempsey, I. and M. Valentine. 2017. "Special education Outcomes and Young Australian School Students: A Propensity Score Analysis Replication.” Australasian Journal of Special and Inclusive Education 41 (1): 68-86. Retrieved from https://search-proquest com.ezproxy.une.edu.au/docview/1913348688?rfr_id=info\%3Axri\%2Fsid\%3Aprimo

Deloitte Access Economics. 2017. Review of Education for Students With Disability in Queensland State Schools. Brisbane, Australia: Department of Education and Training, Queensland Government.

Denniss, R. 2018. "Dead Right: How Neoliberalism Ate Itself and What Comes Next." Quarterly Essay 1 (70): 1-79. https://search-informit-com-au.ezproxy.une.edu.au Dinham, S. 2008. "Diversity in Australian education." Teaching and Learning and Leadership. ACER. Retrieved from http://research.acer.edu.au/tll_misc/10 Education and Employment References Committee. 2016. Access to Real Learning: The Impact of Policy, Funding and Culture on Students with Disability. Canberra, Australia: Commonwealth of Australia.

Fischer, K. and S. Robinson. June 28 2017. Census Shows Increase in Children with Disability, but Even More are Still Uncounted. Commentary in The Conversation. Melbourne, Australia: The Conversation Media Group. Retrieved from https://theconversation.com/census-shows-increase-in-children-with-disability-buteven-more-are-still-uncounted-80143

Foley, G. and E. Muldoon. August 15 2014. Pyning for Indigenous Rights in the Australian Curriculum. Commentary in The Conversation. Melbourne, Australia: The Conversation Media Group. Retrieved from https://theconversation.com/pyning-forindigenous-rights-in-the-australian-curriculum-30422

Forlin, C. 2006. "Inclusive Education in Australia Ten Years After Salamanca". European Journal of Psychology of Education 21 (3): 265-277. doi:10.1007/BF03173415

Forlin, C., D. Chambers, T. Loreman, J. Deppeler, and U. Sharma. 2013. Inclusive Education for Students with Disability: A Review of the Best Evidence in Relation to Theory and Practice. Braddon, ACT: Australian Research Alliance for Children and Youth.

Furlong, J. 2013. "Globalisation, Neoliberalism, and the Reform of Teacher Education in England." The Educational Forum 77 (1): 28-50. doi:

$10.1080 / 00131725.2013 .739017$ 
Glendinning, S. 2015. "Varieties of Neoliberalism.” LSE 'Europe in Question' Discussion Paper Series 1 (89): 1-38. www.lse.ac.uk/europeanInstitute/.../LEQSPaper89.pdf

Gonski, D., T. Arcus, K. Boston, V. Gould, W. Johnson, L. O’Brien, L. Perry, and M. Roberts. 2018. Through Growth to Achievement: Report of the Review to Achieve Educational Excellence in Australian Schools. Canberra: Commonwealth of Australia. Retrieved from https://docs.education.gov.au/documents/through-growthachievement-report-review-achieve-educational-excellence-australian-0

Gonski, D., K. Boston, K. Greiner, C. Lawrence, C., B. Scales, and P. Tannock. 2011. Review of Funding for Schooling. Final Report. Canberra: Commonwealth of Australia. Retrieved from

http://www.deewr.gov.au/Schooling/ReviewofFunding/Documents/Review-ofFunding-for-Schooling-Final-Report-Dec-2011.pdf]. Accessed 25/07/14.

Graham, L. 2018. "Questioning the Impacts of Legislative Change on the Use of Exclusionary Discipline in the Context of Broader System Reforms: A Queensland Case-study." International Journal of Inclusive Education. doi: $10.1080 / 13603116.2018 .1540668$

Graham, L. 2016. "Reconceptualising Inclusion as Participation: Neoliberal Buck-Passing or Strategic By-Passing?” Discourse: Studies in the Cultural Politics of Education 37 (4): 563-581. doi: 10.1080/01596306.2015.1073021

Graham, L. 2015. “A Little Learning is a Dangerous Thing: Factors Influencing the Increased Identification of Special Educational Needs from the Perspectives of Education Policymakers and School Practitioners." International Journal of Disability, Development and Education 62 (1): 116-132. doi: 10.1080/1034912X.2014.955791

Hall, K., J. Collins, S. Benjamin, M. Nind, and K. Sheehy. 2004. "SATurated Models of Pupildom: Assessment and Inclusion/Exclusion.” British Educational Research Journal 30 (6): 801-872. doi:10.1080/0141192042000279512

Hancock, K., C. Shepherd, D. Lawrence, and S. Zubrick. 2013. Student Attendance and Educational Outcomes: Every day counts. Canberra, Australia: Department of Education, Employment and Workplace Relations. Retrieved from https://www.researchgate.net/publication/254863068_Student_Attendance_and_Educ ational_Outcomes_Every_Day_Counts

Harris, K. 1979. Education and Knowledge: The Structured Misrepresentation of Reality. London, United Kingdom: Routledge \& Kegan Paul. 
Human Rights Watch (HRW). 2018. I needed help, Instead I was Punished: Abuse and neglect of prisoners with Disabilities in Australia. Retrieved from https://www.hrw.org/report/2018/02/06/i-needed-help-instead-i-was-punished/abuseand-neglect-prisoners-disabilities\#

Hutchings, M. 2017. “Accountability Measures: The Factory Farm Version of Education.” The Psychology of Education Review 41 (1): 3-15. Retrieved from http://web.b.ebscohost.com.ezproxy.une.edu.au

Jagose, A., L. Wallace, and V. Rawlings. Feburary 15 2019. Pages and Prejudice: How Queer Texts Could Fight Homophobia in Australian Schools. Commentary in The Conversation. Melbourne, Australia: The Conversation Media Group. Retrieved from https://theconversation.com/pages-and-prejudice-how-queer-texts-could-fighthomophobia-in-australian-schools-111437

Lamb, S., J. Jackson, A. Walstab, and S. Huo. 2015. Educational Opportunity in Australia 2015: Who Succeeds and Who Misses Out. Centre for International Research on Education Systems, Victoria University, for the Mitchell Institute, Melbourne: Mitchell Institute.

Loreman, T. 2014. "Measuring Inclusive Education Outcomes in Alberta, Canada." International Journal of Inclusive Education 18 (5): 459-483. doi: 1080/13603116.2013.78822310

Loreman, T., J. Deppeler, and D. Harvey. 2011. IE: Supporting Diversity in the Classroom. Crows Nest, Australia: Allen and Unwin.

Mayes, E. and A. Howell. 2018. "The (hidden) Injuries of NAPLAN: Two Standardised Test Events and the Making of 'at risk' Student Subjects." International Journal of Inclusive Education 22 (10): 1108-1123. doi: 10.1080/13603116.2017.1415383

Miller, E., T. Ziaian, and A. Esterman. 2018. "Australian School Practices and the Education Experiences of Students With a Refugee Background: A Review of the Literature.” International Journal of Inclusive Education 22 (4): 339-359. doi:

$10.1080 / 13603116.2017 .1365955$

Ministerial Council on Education, Employment, Training and Youth Affairs. 2008.

Melbourne Declaration on Educational Goals for Young Australians. Carlton South: MCEETYA.

Mulcahy, D. 2008. The Educated Person. Maryland, United States of America: Rowman \& Littlefield. 
NAP. 2017. National Assessment Program Literacy and Numeracy: National report for 2017. Sydney: ACARA. Retrieved from http://www.nap.edu.au/results-andreports/national-reports

NAP. 2016a. Adjustments for Students with Disability. Sydney: ACARA. Retrieved from https://www.nap.edu.au/naplan/school-support/adjustments-for-students-withdisability

NAP. 2016b. National Assessment Program Literacy and Numeracy. Sydney: ACARA. Retrieved from http://www.nap.edu.au

Niesche, R. and A. Keddie. 2016. Leadership, Ethics and Schooling for Social Justice. Oxon \& New York: Routledge.

OECD. 2018. Equity in Education: Breaking Down Barriers to Social Mobility. Paris: OECD Publishing.

Perry, L. March 15 2017. Educational Disadvantage is a Huge Problem in Australia - We Can't Just Carry on the Same the Conversation. Commentary in The Conversation. Melbourne, Australia: The Conversation Media Group. Retrieved from https://theconversation.com/educational-disadvantage-is-a-huge-problem-in-australiawe-cant-just-carry-on-the-same-74530

Reindal, M. 2016. "Discussing Inclusive Education: An Inquiry Into Different Interpretations and a Search for Ethical Aspects of Inclusion Using the Capabilities Approach.” European Journal of Special Needs Education 31 (1): 1-12. doi: $10.1080 / 08856257.2015 .1087123$

Riddle, S. March 14 2017. Parents Shouldn't Rely on My School Data when Choosing a School for Their Child. Commentary in The Conversation. Melbourne, Australia: The Conversation Media Group. Retrieved from https://theconversation.com/parentsshouldnt-rely-on-my-school-data-when-choosing-a-school-for-their-child-74301

Rowe, E. and C. Lubienski. 2017. "Shopping for Schools or Shopping for Peers: Public Schools and Catchment Area Segregation.” Journal of Education Policy 32 (3): 340356 doi: 10.1080/02680939.2016.1263363

Roy, D. July 11, 2016. More Parents are Choosing to Homeschool Their Children - Why?. Commentary in The Conversation. Melbourne, Australia: The Conversation Media Group. Retrieved from https://theconversation.com/more-parents-are-choosing-tohome-school-their-children-why-60787

SBS. 2018. The Employables. Retrieved from https://www.sbs.com.au/guide/article/2018/07/23/ 
Schwab, S., U. Sharma, and T. Loreman. 2018. "Are We Included? Secondary Students' Perception of Inclusion Climate in Their Schools." Teaching and Teacher Education 75 (1): 31-39. doi:10.1016/j.tate.2018.05.016

Shahaeian, A. November 21 2014. Diversity in the Classroom Means Children Develop Differently. Commentary in The Conversation. Melbourne, Australia: The Conversation Media Group. Retrieved from https://theconversation.com/diversity-inthe-classroom-means-children-develop-differently-33899

Slee, R. 2018. Inclusive Education isn't Dead, it Just Smells Funny. Abingdon, Oxon: United Kingdom.

Statham, A. January 15 2014. 'Secular': An Aspiration or a Dirty Word in Australian Education? Commentary in The Conversation. Melbourne, Australia: The Conversation Media Group. Retrieved from https://theconversation.com/secular-anaspiration-or-a-dirty-word-in-australian-education-22004

Sweller, N., L. Graham, and P. Van Bergen. 2012. "The Minority Report: Disproportionate Representation in Australia's Largest Education System." Exceptional Children 79 (1): 107-125. doi:10.1177/001440291207900106

UNESCO. 1994. The Salamanca Statement and Framework for Action on Special Needs Education. Paris, France: UNESCO. 


\begin{tabular}{|c|c|}
\hline Criteria & Student participation \\
\hline $\begin{array}{l}\text { The Salamanca } \\
\text { Statement says... }\end{array}$ & $\begin{array}{l}\text { 'The guiding principle that informs this Framework is that } \\
\text { schools should accommodate all children regardless of their } \\
\text { physical, intellectual, social, emotional, linguistic or other } \\
\text { conditions. This should include disabled and gifted children, } \\
\text { street and working children, children from remote or nomadic } \\
\text { populations, children from linguistic, ethnic or cultural } \\
\text { minorities and children from other disadvantaged or } \\
\text { marginalized areas or groups' (6). }\end{array}$ \\
\hline
\end{tabular}

The state of play in Australia
- A 2017 survey (Children and Youth with Disability Australia (CYDA)) found $12 \%$ of respondents indicated that at some point, their child had been refused enrolment on the grounds of inadequate resources or supports, and $38 \%$ described an event or activity that their child was excluded from on the grounds of disability. This is despite this practice being illegal under the DSE (2005).

- Aboriginal and Torres Strait Islander student attendance rates have not improved since 2014. Attendance is at $82 \%$, while for their non-indigenous peers it is $93 \%$ (CTG 2019).

- Students from low socio-economic backgrounds have significantly lower rates of attendance (Hancock et al. 2013).

- Students living in regional and remote areas have lower rates of attendance than their city counterparts (AIHW 2018).

- Student attendance has decreased slowly over the past decade, with the biggest decrease attributed to students enrolled in government schools (NAP 2016b).

- The number of students with disability being homeschooled is increasing (Roy 2016).

- The number of students attending special schools has increased from $4.4 \%$ in 2010 , to $4.9 \%$ in 2016 (ABS 2017).

- Students from disadvantaged backgrounds are disproportionality represented in the populations of special and segregated school settings (Cooc and Kiru 2018; Sweller, Graham, and Van Bergen 2012).

- In 2015 around 3\% of students with a disability were not attending school, a number which had increased from around 2\% since the early 2000's (AIHW 2017).

- The numbers of students being suspended and excluded from schools in Australia is increasing, and disadvantaged children, children with a disability, Indigenous children and children in out-of-home care 
are all significantly overrepresented in these statistics

(Graham 2018).

\begin{tabular}{ll}
\hline Criteria & Student achievement \\
\hline The Salamanca & 'The fundamental principle of the inclusive school is that all \\
Statement says... & $\begin{array}{l}\text { children should learn together, wherever possible, regardless of any } \\
\text { difficulties or differences they may have. Inclusive schools } \\
\text { must recognize and respond to the diverse needs of their } \\
\text { students, accommodating both different styles and rates of learning } \\
\text { and ensuring quality education to all through appropriate curricula, } \\
\text { organizational arrangements, teaching strategies, resource use and } \\
\text { partnerships with their communities. There should be a continuum of } \\
\text { support and services to match the continum of special needs } \\
\text { encountered in every school' (11 \&12). }\end{array}$ \\
\hline
\end{tabular}

The state of play in Australia
- Students with parents who have lower levels of educational attainment, are not in paid work, are indigenous, are from a language background other than English, or live outside metropolitan areas are likely to achieve significantly lower results in the NAPLAN testing that their peers who have parents with high levels of education, are in regular paid employment, are non-indigenous, are from an English speaking background and live in the city (ACARA 2017).

- Students from low socio-economic status are less likely to complete Year 12 than students from high socioeconomic status (ACARA 2017).

- Aboriginal and Torres Strait Islander students represent a disproportionally high number of those who do not meet the national minimum standards in NAPLAN, however it should be noted that some gains have been made here as the gap is narrowing (CTG 2019).

- The gap between Aboriginal and Torres Strait Islander students and their non-indigenous peers with Year 12 attainment has narrowed from $36 \%$ in 2006 to $24 \%$ in 2016.

- Students from Aboriginal and Torres Strait Islander backgrounds are still under represented in universities across Australia (CTG 2019), and Aboriginal males are twice as likely to go to prison than university (Cunneen 2013).

- Students with a disability are twice as likely to not successfully complete Year 12 or an equivalent qualification as their non-disabled peers (AIHW 2017).

- Students who attend special schools achieve lower outcomes that their peers who attend mainstream schools (Dempsey and Valentine 2017).

\begin{tabular}{ll}
\hline Criteria & Postschool outcomes \\
\hline The Salamanca & $\begin{array}{l}\text { 'The merit of (inclusive) schools is not only that they are capable of } \\
\text { Statementiding quality education to all children; their establishment is a } \\
\text { crucial step in helping to change discriminatory attitudes, in creating }\end{array}$ \\
\hline
\end{tabular}


welcoming communities and in developing an inclusive society' (6

\& 7).

The state of play in Australia
- Prison populations in Australia are increasing. From June 2017 to June 2108 the number of people being incarcerated increased by $3 \%$, and people with a disability, a mental health disorder, from low socioeconomic or indigenous backgrounds are all significantly over-represented in the prison populations (HRW 2018).

- A large gap in life expectancy exists between indigenous and non-indigenous Australian's, with males expected to live 8.6 years less than their nonindigenous counterparts, and females 7.8 years less (CTG 2019).

- A large gap in life expectancy exists between the lowest and highest socio-economic groups, with the life expectancy for those in the lowest group 5.7 years less for males and 3.3 years less for females (AIHW 201).

- Aboriginal and Torres Strait Islander people have less chance of gaining employment once they leave school. While employment rates for this group of Australians' fell from $48 \%$ in 2008 to less than $47 \%$ in 2016, the gap in employment between Aboriginal and Torres Strait Islander people and the rest of Australia's population increased by $1.5 \%$ over the same period, to $25 \%$ (CTG 2019).

- Immigrants and refugees, the LGBTIQ+ community, people with disabilities, and former prisoners are all overrepresented in Australia's unemployment statistics SBS (2018).

- A 2017 report (Brotherhood of St Laurence and the Melbourne Institute) found that $22 \%$ of Australians aged 15 years and over experienced some form of social isolation. Groups most likely to experience this include Aboriginal and Torres Strait Islander people, people with a disability or chronic health issue (including mental health), early school leavers and immigrants from non-English speaking countries (AIHW 2018). 